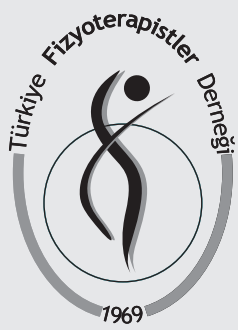

Türk Fizyoterapi ve Rehabilitasyon Dergisi

$201627(3) 81-88$

Derya ÇELIK, PT, PhD, Assoc Prof. Nilgün TÜRKEL, PT, MSc. ${ }^{2}$ Ata Can ATALAR, MD, Prof. ${ }^{3}$

Geliş Tarihi: 23.11 .2015 (Received) Kabul Tarihi: 05.08.2016 (Accepted)

İletişim (Correspondence):

Derya Çelik, PT, PhD, Assoc Prof. Istanbul University, Faculty of Health Sciences, Division of Physiotherapy and Rehabilitation, 34740 Bakırkoy, Istanbul, Turkey

email:ptderya@hotmail.com

1 Istanbul University, Faculty of Health Sciences, Division of Physiotherapy and Rehabilitation, Istanbul, Turkey

2 Istanbul University, Faculty of Medicine, Department of Orthopaedics and Traumatology, Istanbul, Turkey

3 Istanbul University, Faculty of Medicine, Department of Orthopaedics and Traumatology, Istanbul, Turkey

\section{COMPARISON OF MATRIX RHYTHM THERAPY AND STRETCHING EXERCISES ON FROZEN SHOULDER: RANDOMISED CONTROLLED TRIAL}

\section{RESEARCH ARTICLE}

\section{ABSTRACT}

Purpose: To compare the short-term effectiveness of Matrix Rhythm Therapy and stretching exercises in patients with frozen shoulder.

Methods: Forty-three patients (mean age 52.6 years) with frozen shoulder were randomly assigned to one of 2 treatment groups: Matrix Rhythm Therapy group and stretching exercises group. Both groups were treated for 6 weeks and performed the same home exercise program. The range of motion was measured using a conventional goniometer. Constant score and the Disabilities of the Arm, Shoulder and Hand score was used for functional assessment. General health status and satisfaction of the patients were evaluated by Short Form Health Survey-36 and Global Rating of Change score, respectively. The changes in dependent variables before treatment and after 3, 6 weeks of treatment and 24 weeks of follow-up were analyzed using $2 \times 5$ mixed-model analysis of variance (ANOVA) to assess overall group, time, and group interaction effects.

Results: Both groups had significant improvement in all outcome measurements $(p<0.05)$. Two by 5 mixed-model ANOVA revealed a significant group-time interaction for Constant score $(p=0.009)$ and Short Form Health Survey-36 physical component score $(p=0.009)$ patients receiving stretching exercise at 24 weeks' follow-up. Pairwise comparison showed that SF-36 physical component score at 6 weeks and Constant score at 3 and 6 weeks follow ups were better in stretching exercise group.

Discussion: The patients improved with both treatment strategies; however, stretching exercise was found to be superior to Matrix Rhythm Therapy for function, physical health, and satisfaction of the patients.

Key words: Adhesive capsulitis; pain measurement; shoulder pain; recovery of function

\section{DONUK OMUZDA MATRIKS RITM TERAPI VE GERME EGZERSIZLERININ KARŞILAŞTIRILMASI: RANDOMIZE KONTROLLÜ ÇALIŞMA}

\section{ARAŞTIRMA MAKALESi}

\section{ÖZ}

Amaç: Donuk omuzhastalarında Matriks Ritm Terapinin kısa dönem etkilerini değerlendirmekti. Yöntemler: Donuk omuz tanısı konan 43 hasta (ortalama yaş; 52.6 yıl, aralık 44-67 yıl) randomize olarak 2 tedavi grubuna ayrıldı: Matriks Ritm Terapi grubu ve germe egzersizleri grubu. Her iki grup 6 hafta tedavi edildi ve ev egzersiz programı verildi. Eklem hareket açıklı̆̆ı konvansiyonel gonyometre ile, ağıı Görsel Analog Skala ile fonksiyonel durum Constant ve DASH-T skoru ile değerlendirildi. Hastaların genel sağlık durumu Kısa Form36 ve memnuniyeti global değişim skoru ile incelendi. Bağımsız değişkenlerdeki değişimler tedaviden önce, tedaviden sonra 3., 6. ve 24. haftada $2 \times 5$ mixed model ANOVA ile hesaplandı.

Sonuçlar: Her iki grup da tüm sonuç ölçümlerine göre anlamlı olarak iyileşti $(p<0.05) .2 \times 5$ mixed model ANOVA ile, Kısa Form-36'nın fiziksel toplam skoru $(p=0.009)$ ve Constant skoru (0.009), grup-zaman ilişkisi açısından germe egerszileri yapılan grupta 24. haftada anlamlı bulundu. Paired Simple T test bu farkın germe egzersiz grubunda Constant skorunda 3 ve 6 . haftada, Kısa Form-36 fiziksel toplam skorunda ise 6. haftadaki gelişmeden olduğunu ortaya koydu.

Tartışma: Her iki tedavi grubunda da hastalar belirgin olarak düzeldi fakat germe egzersizleri grubu fonksiyon, genel fiziksel sağlık ve hasta memnuniyeti açısından Matriks Ritm Terapi grubuna göre daha iyi bulundu.

Anahtar kelimeler: Donuk omuz; ağrı değerlendirmesi; omuz ağrısı; fonksiyonun iyileşmesi 


\section{INTRODUCTION}

Frozen shoulder or adhesive capsulitis, is characterized by pain and gradual restriction of the shoulder motion. The cause of a frozen shoulder is not well known and it often occurs for unknown reasons. Frozen shoulder is reported to affect $2 \%$ to $5 \%$ of the general population (1-3). Factors associated with frozen shoulder include female gender, being over 40 years of age, trauma, immobilization, diabetes, thyroid disease, stroke and complex regional pain syndrome $(4,5)$.

The definitive treatment for frozen shoulder remains unclear even though many interventions have been studied including active/passive range of motion (ROM) exercises, stretching, soft tissue mobilization, myofascial release, proprioceptive-neuromuscular facilitation techniques, ultrasound, electrical stimulation, ice packs and joint mobilization techniques (6-13). Unfortunately, varied inclusion criteria, different treatment protocols, different treatment sessions, various outcome measurements and natural course of recovery make study comparison difficult.

Stretching is one of the treatment strategies in the management of decreased ROM due to joint capsule/ligaments stiffness. Stretching influences tissue remodeling and provides plastic deformation, which is the result of gaining ROM. The Matrix-Rhythm-Therapy (MRT) directly derived from the clinical and fundamental video-microscopic research of Erlangen University (Dr. Randoll) in the 1990's is a treatment device that activates and rebalances specific physiological vibrations of skeletal muscles and nervous system (14). It basically works against it and improves the tissue extensibility, and also the circulation. As a result of hypoxia or an energy deficit on the cellular level, the muscles fibers become contracted. The contracted muscle fibers are no longer available for active motion. The variability of the motion pattern is restricted. MRT is thought to increase the ROM, induce relaxation, modulate pain and reduce soft tissue swelling and inflammation (14).

There are a few studies and clinical experience that indicate the effectiveness of MRT (15-17) but there is not any study which used MRT in treatment of frozen shoulder. The hypothesis of the study was that, stretching exercises (STE) would be more effective than MRT in subjects with frozen shoulder. The aim of the study was to compare the effectiveness of MRT and STE in patients with frozen shoulder.

\section{METHODS}

\section{Subjects}

The patients were initially examined by orthopedic surgeons from the Istanbul University, Faculty of Medicine, Department of Orthopedics and Traumatology. Radiographic and magnetic resonance imaging results were assessed by the orthopedic surgeons to determine the presence of other pathologies. Subjects who fulfilled the following criteria were included in the study:

1) ROM in external rotation, abduction, and flexion of less than $50 \%$ in comparison to the contralateral shoulder in 1 or more of 3 movement directions (i.e., abduction in the frontal plane, forward flexion, or external rotation at $0^{\circ}$ abduction); 2) Normal radiographic results (anteroposterior and lateral views); 3) Duration of complaint of more than three months; 4) Ability to read and understand Disabilities of the Arm, Shoulder and Hand score (DASH-T) and SF-36 questionnaires in Turkish; 5) Patients diagnosed with primary frozen shoulder.

Subjects with the following conditions were not included in the study: 1) Cervical radiculopathy and radiating pain from the either wrist or a hand; 2 ) Thoracic outlet syndrome; 3) Rheumatological disorders; 4) Fractures or tumors of either upper extremity; 5) Neurological disorders that cause muscle weakness in the shoulder; 6) Corticosteroid injections in the affected shoulder within the previous four weeks; 7) Rotator cuff tears.

\section{Sample size and randomization}

The sample size and power calculations were performed with the Instant sample size calculator. The calculations were based on a standard deviation of 12 points, a between-group difference of 11 points (which represents the minimal clinically important difference $[M C I D]$ (DASH-T), an alpha level of .05 , and $\beta$ level of $20 \%$ and a desired power of $80 \%$. These parameters generated a sample size of at least 20 patients of each group. Allowing for a conservative dropout rate, 51 subjects were rec- 
Table 1: Demographic Features

\begin{tabular}{|l|c|c|c|}
\hline & $\begin{array}{c}\text { Matrix } \\
\text { RhythmTherapy } \\
\text { Group } \\
(\mathbf{n = 2 1 )}\end{array}$ & $\begin{array}{c}\text { Stretching } \\
\text { Group } \\
\mathbf{( n = 2 2 )}\end{array}$ & p value \\
\hline Age.years (range) & $53.1(42-65)$ & $52.7(40-65)$ & $0.73^{*}$ \\
\hline Female/Male & $16 / 5$ & $14 / 6$ & $0.39 \dagger$ \\
\hline Dominant Side R/L & $20 / 1$ & $20 / 2$ & $0.31 \dagger$ \\
\hline Involved Dominant/Non-Dominant & $15 / 6$ & $13 / 9$ & $0.59 \dagger$ \\
\hline
\end{tabular}

SD: Standart Deviation, R: Right, L: Left , * t-test for between group comparison, † Chi-square test for between group comparisons

ruited in the study. This sample size predicted greater than $80 \%$ power to detect both statistically significant and clinically meaningful changes in the DASH-T. The patients received written and verbal explanations of the purpose of the study and of the procedures to be applied. If they agreed to participate, they signed an informed consent form which was approved by the ethics committee at Istanbul University, Faculty of Medicine (IRB study protocol: 2010-894-264). Patients were randomly assigned into two groups using a computer-gene- rated randomized table of numbers created prior to the beginning of the study. Individual, sequentially numbered index cards with the random assignment were prepared. The index cards were folded and placed in sealed opaque envelopes. Each envelope was then opened by a researcher who was blinded to the baseline examination findings, and treatment proceeded according to the group assignment. MRT group consisted of 26 and STE group consisted of 25 patients. Five participants in MRT and 3 participants in STE group did not complete

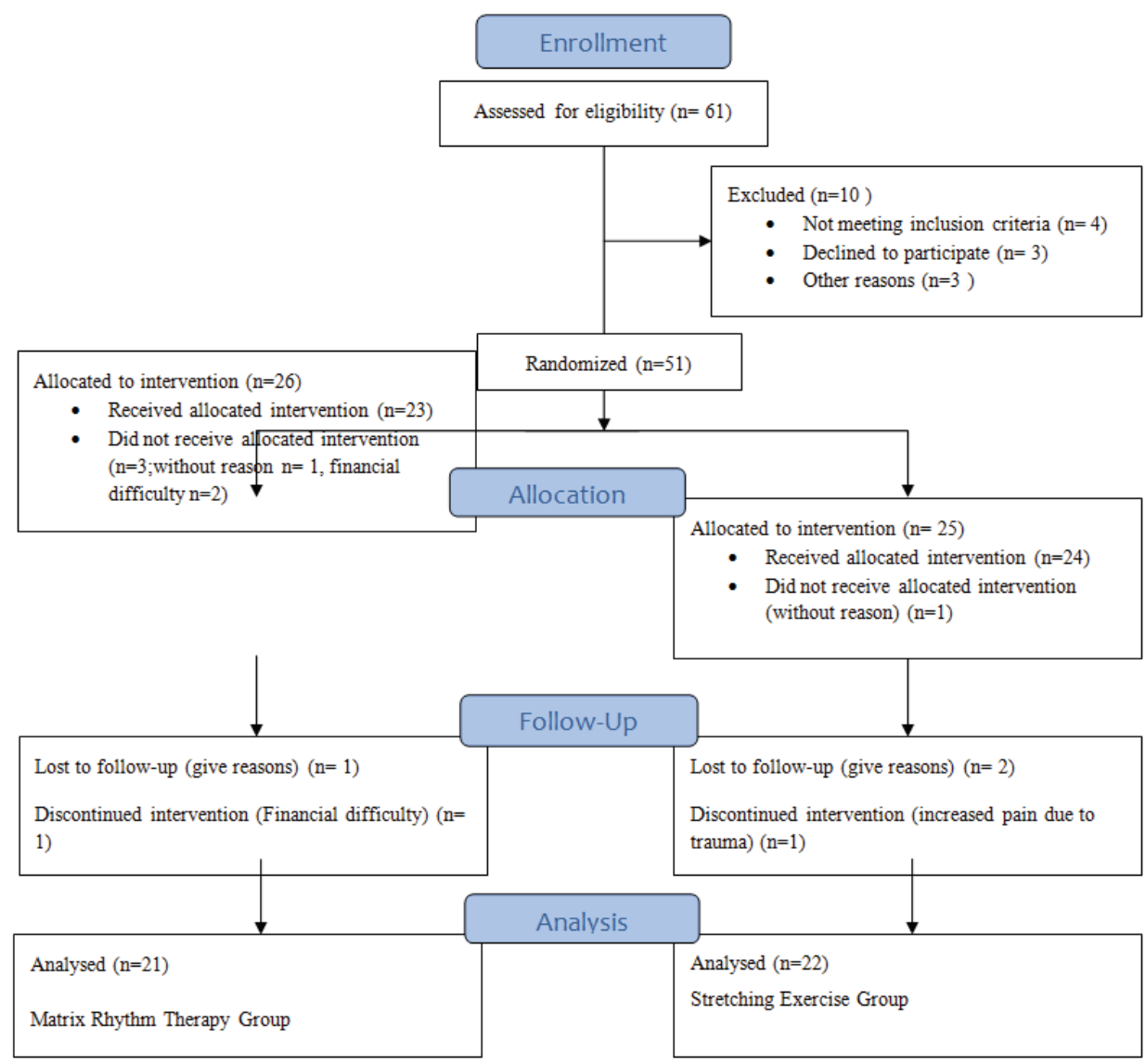

Figure 1: Follow diagram 
the protocol. Therefore, 21 patients (16 females, mean age 53.1, age range 42-65 years) were included in MRT group and a total of 22 patients (14 females, mean age 52.7, age range 40-65 years) participated in STE group (Table 1) (Fig 1. Follow diagram)

\section{Interventions}

\section{Matrix Rhythm Therapy}

MRT (MaRhyThe1 Applikator\&Steuer-gerat, MaRhyThe1 Systems GmbH, Grobenzell, Germany) was applied by the same physical therapist who participated in the training program on MRT and was certificated. It was applied over 45 minutes starting from shoulder girdle and including scapula and pectoralis major. Patients were in the supine position and MRT was applied around the scapular muscles (trapezius, latissimus dorsi and serratus anterior) and supraspinatus for 15 minutes. Then the patients were given prone position and MRT was applied around pectoralis muscles. Finally for the remaining 15 minutes, MRT was applied on deltoids, biceps and triceps muscles. The MRT was applied parallel to the fibers of muscle groups (Figure 2). The patients received treatment at the clinic, 3 times a week (totaling 18 sessions).

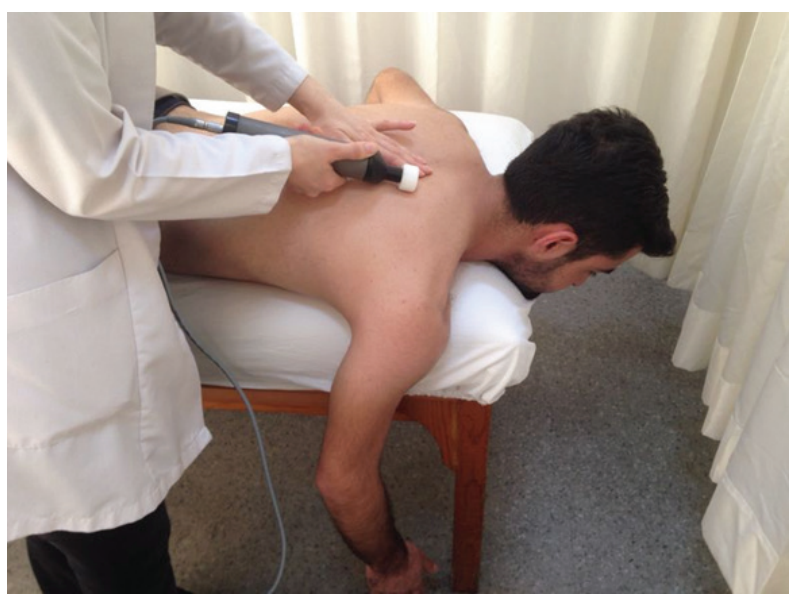

Figure 2: The application of MRT over scapular muscles

\section{Stretching Exercises}

The cyclic (intermittent) stretching technique was applied to the patients lying in bed. Cyclic stretching is a relatively short-duration stretch force that is repeatedly but gradually applied, released, and then reapplied $(18,19)$. It was applied 10-15 times in each direction. The total duration of stretching exercises was 20 minutes. Sessions took place 3 times a week to minimize post-exercise soreness and to allow tissue healing. The STE were as follows: Forward flexion, scapular plane abduction, external rotation in the scapular plane and internal rotation in a half-side lying position (Figure 3).

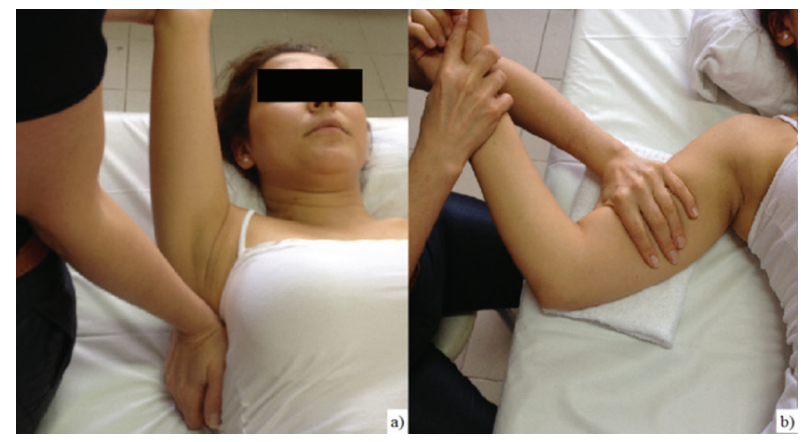

Figure 3: Stretching exercises
a) Forward flexion
b) External rotation in scapular plane

\section{Home exercises}

Both groups performed the same home exercise program consisting of self-stretching and strengthening exercises. The patients were taught how to stretch with low load and duration, depending on pain tolerance. The self-conducted exercises were performed twice a day with 20 repetitions of each movement. Strengthening exercises for the scapulothoracic and rotator cuff muscles with tubing were done twice a day with 10 repetitions of each movement and the application of a cold pack for pain. The home exercises were as follows: (1) self-stretching: shoulder flexion on the table; (2) self-stretching: shoulder abduction on the table; (3) self-stretching: internal rotation of the shoulder (sleeper stretch); (4) posterior capsule stretching; (5) scapular retraction with tubing; (6) external rotation with tubing; (7) extension with tubing; (8) wall and table push-ups; (9) scapular adduction in prone position.

\section{Outcomes}

The passive ROM of each subject, including abduction in the frontal plane, forward flexion, external and internal rotation in $30^{\circ}$ abduction, were measured as described by Clarkson et al, using a conventional goniometer (20). 
Functional disability was measured using the Turkish versions of the Constant score and DASH-T $(21,22)$. Constant score comprises 4 subscales including pain, activities of daily living, active ROM, and abduction strength. The total Constant score ranges from 0 to 100, with higher scores indicating better function. The DASH-T questionnaire is a 30-item scale of disability symptoms used to assess a patient's health status. Questions are asked about the degree of difficulty experienced due to an arm, shoulder or hand problem (21 items) when performing various physical activities. The scores obtained from all items are then used to calculate a score ranging from 0 (no disability) to 100 (most severe disability).

The SF-36 was used to establish a health profile that consists of eight scaled scores, where each scale was directly transformed into a scale from 0-100 in order to identify the patient's physical and mental state. These 8 sections include physical functioning, physical role functioning, bodily pain, general health perceptions, vitality, social function, emotional role functioning, and mental health. In addiation, the sum of the physical functioning, physical role functioning, bodily pain, and general health perceptions subscales generates a physical component sum $\neg$ mary score (PCS), and the sum of the vitality, social function, emotional role functioning, and mental health subscales generates a mental component summary score (MCS) (23).

Global rating of change (GRC) scales are designed to quantify a patient's improvement or deterioration over time, usually either to determine the effect of an intervention or to chart the clinical course of a condition (24). The responses for the GRC were "much better"; "slightly better"; "stayed the same"; "slightly worse" or "much worse".

Assessments were performed at baseline, 3, 6 weeks of treatment and 24 weeks of follow-up by another therapist who did not know the study groups or the procedures.

\section{Data analysis}

The data were evaluated using the Statistical Package for the Social Sciences 15.0 program for Windows and by analyzing descriptive statistics (frequency, mean and standard deviation). Before the statistical analysis, a Kolmogorov-Smirnov

Table 2: The comparison of ROM, Constant and DASH score, SF-36 in two groups at baseline to follow-ups

\begin{tabular}{|c|c|c|c|c|c|c|c|}
\hline Assessments & Group & $\begin{array}{c}\text { Baseline Mean } \\
(95 \% \mathrm{Cl})\end{array}$ & $\begin{array}{c}\text { 3-week Mean } \\
(95 \% \mathrm{Cl})\end{array}$ & $\begin{array}{c}\text { 6-week Mean } \\
(95 \% \mathrm{CI})\end{array}$ & $\begin{array}{c}\text { 24-week Mean } \\
(95 \% \mathrm{Cl})\end{array}$ & $\mathbf{F}$ & $\mathbf{p}^{* *}$ \\
\hline \multirow{2}{*}{ Flexion } & MRT & $117(104-131)$ & 149.0 (139-159) & $160.3(152-170)$ & $167.6(158-176)$ & \multirow{2}{*}{1.5} & \multirow{2}{*}{0.22} \\
\hline & STE & 131.1 (120-145) & 159.6 (149-169) & 166.8 (159-175) & $162.9(155-173)$ & & \\
\hline \multirow{2}{*}{ Abduction } & MRT & $82.5(72-92)$ & $112.9 .0(96-127)$ & $133.0(117-148)$ & 140.4 (121-159) & \multirow{2}{*}{1.4} & \multirow{2}{*}{0.24} \\
\hline & STE & $95.6(85-105)$ & $127.1(111-143)$ & $143.2(128-158)$ & $144.6(126-162)$ & & \\
\hline \multirow{2}{*}{$\begin{array}{l}\text { External } \\
\text { Rotation }\end{array}$} & MRT & $28.7(19-36)$ & $43.4(32-53)$ & $53.7(45-62)$ & $53.6(42-63)$ & \multirow{2}{*}{3.4} & \multirow{2}{*}{0.07} \\
\hline & STE & $27.5(21-37)$ & $52.6(44-64)$ & $64.6(58-74)$ & $67.6(59-78)$ & & \\
\hline \multirow{2}{*}{$\begin{array}{l}\text { Internal } \\
\text { Rotation }\end{array}$} & MRT & $36.5(33-47)$ & $54.9(50-68)$ & $64.2(58-77)$ & $67.5(57-77)$ & \multirow{2}{*}{0.08} & \multirow{2}{*}{0.92} \\
\hline & STE & $39.7(31-44)$ & $59.6(49-66)$ & $67.6(58-75)$ & $66.5(58-74)$ & & \\
\hline \multirow{3}{*}{$\begin{array}{l}\text { Constant } \\
\text { Score }\end{array}$} & MRT & $34.0(27-41)$ & $53.9(48-61)$ & $62.0(54-70)$ & $71.0(62-80)$ & \multirow{3}{*}{8.0} & \multirow{3}{*}{0.009} \\
\hline & STE & $49.4(43-56)$ & $69.9(63-75)$ & $75.4(66-82)$ & $78.9(70-87)$ & & \\
\hline & $\mathrm{p}^{*}$ & 0.003 & 0.002 & 0.039 & 0.21 & & \\
\hline \multirow{2}{*}{ DASH Score } & MRT & $56.6(44-69)$ & $43.1(32-54)$ & $33.7(25-43)$ & $24.3(14-35)$ & \multirow{2}{*}{1.2} & \multirow{2}{*}{0.28} \\
\hline & STE & $59.8(48-72)$ & $37.1(27-47)$ & $18.5(15-27)$ & $15.8(12-25)$ & & \\
\hline \multirow{3}{*}{ SF-36 PCS } & MRT & $34.3(30-39)$ & $37.3(34-41)$ & $38.7(35-43)$ & $41.7(36-48)$ & \multirow{3}{*}{8.1} & \multirow{3}{*}{0.009} \\
\hline & STE & $37.3(32-40)$ & $40.7(35-43)$ & $48.8(48-51)$ & $53.2(48-60)$ & & \\
\hline & $\mathrm{p}^{*}$ & 0.46 & 0.44 & 0.01 & 0.009 & & \\
\hline \multirow{2}{*}{ SF-36 MCS } & MRT & $41.5(36-47)$ & $40.0(35-46)$ & 42.7 (37-49) & $43.3(37-50)$ & \multirow{2}{*}{1.9} & \multirow{2}{*}{0.17} \\
\hline & STE & $43.5(35-46)$ & $44.6(39-50)$ & $49.0(43-54)$ & $52.7(46-59)$ & & \\
\hline
\end{tabular}

MRT: Matrix Ritm Therapy, STE: Stretching exercises, ER: External Rotation, IR: Internal Rotation, DASH: Disabilities of the Arm, Shoulder and Hand, PCS: Physical component score, MCS: Mental component score

$\mathrm{p}^{*}$ : Pairwise comparisons at each period, $\mathrm{p}^{* *}$ Repeated measure ANOVA 
Test was used to assess the distribution of data. Our data were found to be normally distributed, so a parametric test was used for statistical analysis. Demographic comparisons of the two groups were conducted using a Chi-square analysis for categorical variables and independent sample t-tests for continuous variables. The changes in dependent variables before treatment and after 3, 6 weeks of treatment and 24 weeks of follow-up were analyzed using a 2 by 5 mixed-model analysis of variance (ANOVA) to assess overall group, time, and group interaction effects. Pairwise comparisons were performed examining the difference between baseline and follow-up periods using the Bonferroni equality at an alpha level of 0.05 .

\section{RESULTS}

The mean duration of the symptoms was 15.7 (14-21 weeks) weeks. Baseline characteristics of gender, dominant side and involved shoulder were not significantly different similar between groups $(P>$.05). Both the MRT and STE groups were found to be significantly effective in the improvement of ROM, functional status, physical health and satisfaction of the patients. The overall group-by-time interaction for the $2 \times 5$ repeated measure ANOVA revealed a significant group-time interaction for Constant score ( $p=0.009)$ and SF-36 PCS ( $p=0.009)$ for patients receiving STE, at 24 weeks follow-up. Pairwise comparison showed that SF-36-PCS at 6 and 24 weeks and Constant score at 3 and 6 weeks follow ups were better in STE group (Table 2). However, confidence intervals of the SF-36 PCS overlap at 24 weeks therefore; it was not interpreted as a significant difference of both groups. According to GRC, $60 \%$ of the MRT group and $71.4 \%$ of the STE group reported that they were much better.

\section{DISCUSSION}

The results of our study show that both methods were found to be significantly effective in the improvement of ROM, functional status, physical health and satisfaction of the patients. Constant score and SF-36 PCS demonstrated a significant improvement over time and were in favor of the STE group.

MRT has been very popular and is a widely used tre- atment device in some of the European countries as well as in Turkey for musculoskeletal problems such as frozen shoulder, carpal tunnel syndrome, plantar fasciitis, fibromyalgia and tendinopathies. However, it is a new treatment method and lacks of scientific support. The MRT device is thought to be compatible with the natural vibration frequency of the muscle, which is considered to contribute to the therapeutic effectiveness of MRT (14). MRT developers believe that decreased circulation of the skeletal muscles causes cramp, pain and limited ROM. The natural vibration of MRT helps circulation of the skeletal muscles and provides oxygen and adenosine triphosphate (ATP), and helps to gain ROM and to reduce pain. One of the previous studies showed that MRT increases the blood circulation by $35 \%$ (17). There are a limited number of studies with a low level of evidence about the effects of MRT on musculoskeletal problems. Jager et al. have assessed the effect of MRT on pain level, sleep patterns and flexibility of the spine in patients with low back pain (25). The results of that study, involving 80 patients, demonstrate that the application of MRT, compared with conservative therapy (including application of warmth, electrotherapy, and exercise), is more effective in reducing pain and increasing flexibility. Randoll and Hennig applied MRT in 65 patients with low back pain over six sessions within a week, and they reported a significant improvement in pain (15). In our study, MRT application increased physical health, function and satisfaction of the patients.

On the other hand, frozen shoulder is generally treated with glenohumeral stretching exercises; however, there are different opinions regarding the appropriate intensity and degree of these exercises. Kelly et al showed that aggressive stretching exercises beyond the pain threshold of patients may exacerbate the symptoms (7). Diercks and Stevens prospectively followed 77 patients with idiopathic frozen shoulder for 24 months to compare the effects of "intensive physical therapy consisting of active exercises up to and beyond the pain threshold, passive stretching, glenohumeral joint mobilization, and home exercises" to "supervised neglect." These authors found that gentle stretching exercises are effective in the treatment of frozen shoulder (26). Griggs et al reported that $90 \%$ of 75 pa- 
tients (mean follow-up, 22 months), classified with stage 2 idiopathic frozen shoulder, demonstrated good outcomes with an exercise program including passive stretching exercises in forward elevation, external rotation, horizontal adduction, and internal rotation and home exercises program which was similar to our program (8). Celik et al compared stretching exercises versus manual therapy combined with stretching exercises. They found that both treatment strategies are effective but some of the outcomes were better with manual therapy (27). We applied the cyclic stretching program in accordance with the pain threshold of the patients. In STE group, all of the outcome measurements improved at the end of treatment (18 visits) and 24 weeks follow-up when compared to baseline. If there is a stiffness or contracture of the soft tissue, we need to provide plastic deformation of the soft tissue which is called "collagen remodeling" to gain ROM. However, the remodeling process occurs in a longer period of time than mechanically induced change that occurs within minutes (1). During our study, every subject received 20 minutes of stretching which helps remodeling of soft tissue and provided better results compared to MRT group. One of the keys to the success of the treatment approach is to gain neuromuscular dynamic control over the newly gained ROM and function. Therefore, the patients have to perform the stretching and strengthening exercises at home to maintain the gained ROM. For this purpose, we selected same exercises as a home program and encouraged the patients for adherence. The patients were asked at each session whether they performed the exercises or not.

There are some limitations: The majority of patients with frozen shoulder significantly improve within a year. Due to lack of a non-intervention group, it is difficult to comment that the interventions applied in this study are superior to the natural recovery process. Therefore, this fact should be taken into consideration while interpreting the results, and future studies should be planned with a longer follow-up period.

\section{Conclusion}

MRT or STE exercises in combination with a home exercise program have beneficial long-term effe- cts on physical health, functional outcomes and satisfaction of patients with frozen shoulder. Even though both groups showed improvement, STE was found to be superior to MRT on physical health, function, and satisfaction of the patients.

\section{REFERENCES}

1. Davies G, Ellenbecker T. Focused exercise aids shoulder hypomobility. Biomechanics. 1999;6:77-81.

2. Bridgman JF. Periarthritis of the shoulder and diabetes mellitus. Ann Rheum Dis. 1972;31(1):69-71.

3. Lundberg J. The frozen shoulder. Clinical and radiographical observations. The effect of manipulation under general anesthesia. Structure and glycosaminoglycan content of the joint capsule. Local bone metabolism. Acta Orthop Scand. 1969;Suppl 119:159.

4. Mao CY, Jaw WC, Cheng HC. Frozen shoulder: correlation between the response to physical therapy and follow-up shoulder arthrography. Arch Phys Med Rehabil. 1997;78(8):857-9.

5. Hannafin JA, Chiaia TA. Adhesive capsulitis. A treatment approach. Clin Orthop Relat Res. 2000;372:95-109.

6. Nitz AJ. Physical therapy management of shoulder. Phys Ther. 1986;66(12):1912-9.

7. Kelly MJ, McClure PW, Leggin BG. Frozen shoulder: evidence and a proposed model guiding rehabilitation. J Orthop Sports Phys Ther. 2009;39(2):135-48.

8. Griggs SM, Ahn A, Green A. Idiopathic adhesive capsulitis. A prospective functional outcome study of nonoperative treatment. J Bone Joint Surg Am. 2000;82:1398-407.

9. Hazleman BL. The painful stiff shoulder. Rheumatol Phys Med. 1972;11(8):413-21.

10. Vermeulen HM, Obermann WR, Burger BJ, Kok GJ, Rozing PM, van Den Ende $\mathrm{CH}$. End-range mobilization techniques in adhesive capsulitis of the shoulder joint: A multiple-subject case report. Phys Ther. 2000;80(12):1204-13.

11. Vermeulen HM, Rozing PM, Obermann WR, le Cessie S, Vliet Vlieland TP. Comparison of high-grade and low-grade mobilization techniques in the management of adhesive capsulitis of the shoulder: randomized controlled trial. Phys Ther. 2006;86(3):355-68.

12. Page MJ, Green S, Kramer S, Johnston RV, McBain B, Buchbinder R. Electrotherapy modalities for adhesive capsulitis (frozen shoulder). Cochrane Database Syst Rev. 2014 Oct 1;10:CD011324.

13. Page MJ, Green S, Kramer S, Johnston RV, McBain B, Chau $M$, et al. Manual therapy and exercise for adhesive capsulitis (frozen shoulder). Cochrane Database Syst Rev. 2014 Aug 26;8:CD011275.

14. Matrix Rhythmus Therapie [home page on the Internet]. Online document at: www.marhythe.in/index.php/aboutmarhyther/ the-therapy Accessed April 14, 2010.

15. Randoll UG, Hennig FF. A new approach for the treatment of low back pain, matrix-rhythm-therapy. Osteologie. 2001; Suppl:66.

16. Randoll UG, Hennig FF. Preoperative and postoperative matrix-rhythm-therapy to optimize hip surgery. Osteologie. 2001;Suppl:149.

17. Taspinar F, Aslan UB, Sabir N, Cavlak U. Implementation of matrix rhythm therapy and conventional massage in young females and comparison of their acute effects on circulation. J Altern Complement Med. 2013;19(10):826-32

18. Bohannon RW. Effect of repeated eight-minute muscle loading on the angle of straight leg raising. Phys Ther. 1984;64:491-7.

19. McNair PJ, Dombroski EW, Hewson DJ, Stanley SN. Stretching 
at the ankle joint: viscoelastic responses to hold and continuous passive motion. Med Sci Sports Exerc. 2001;33(3):354-8.

20. Clarkson HM, Gilewich GB. Musculoskeletal assessment. In: Clarkson HM, editor. Joint range of motion and manual muscle strength. Boltimore: Williams and Wilkins, 1989; p 95-113.

21. Çelik D. Turkish version of the modified Constant-Murley score and standardized test protocol: reliability and validity. Acta Orthop Traumatol Turc. 2016;50(1):69-75.

22. Duger T, Yakut E, Oksuz C, Yorukan S, Bilgutay BS, Ayhan C, et al. Reliability and validity of Turkish version of DASH Questionnaire. Physiother Rehabil. 2006;17(3):99-107.

23. Ware JE Jr, Sherbourne CD. The MOS 36-item short-form health survey (SF-36). Conceptual framework and item selection. Med Care. 1992;30(6):473-83.

24. Kamper SJ, Maher CG, Mackay G. Global rating of change scales: a review of strengths and weaknesses and considerations for design. J Man Manip Ther. 2009;17(3):163-70.

25. Jäger $A$, Chan $D$. The effect of Matrix Rhythm Therapy on back pain patients. 2nd National Physiotherapy and Rehabilitation Congress. 2009 May 14-15; Izmir. P.132.

26. Diercks RL, Stevens M. Gentle thawing of the frozen shoulder: a prospective study of supervised neglect versus intensive physical therapy in seventy-seven patients with frozen shoulder syndrome followed up for two years. J Shoulder Elbow Surg. 2004;13(5):499-502

27. Çelik D, Kaya Mutlu E. Does adding mobilization to stretching improve outcomes for people with frozen shoulder? A randomized controlled clinical trial. Clin Rehabil. 2016;30(8):786-94. 